\title{
Author Correction: Genome-wide analyses of long non-coding RNA expression profiles and functional network analysis in esophageal squamous cell carcinoma
}

\author{
Junliang Ma, Yuhang Xiao, Bo Tian, Shaolin Chen, Baihua Zhang, Jie Wu, Zhining Wu, Xu Li, \\ Jinming Tang, Desong Yang, Yong Zhou, Hui Wang, Min Su \& Wenxiang Wang
}

Correction to: Scientific Reports https://doi.org/10.1038/s41598-019-45493-5, published online 24 June 2019

This Article contains errors.

The numbers of the differentially expressed lncRNAs and microRNAs were inadvertently swapped in the description of the Results. The numbers reported in the Abstract are correct.

As such, in the Results, in the section 'Expression profiles of lncRNAs in ESCC',

"Based on the microarray data, 3,052 lncRNAs and 2,366 mRNAs were identified to be differentially expression (FC $\geq 2.0$ or $\leq 0.5, \mathrm{p} \leq 0.05)$."

should read:

"Based on the microarray data, 2,366 lncRNAs and 3,052 mRNAs were identified to be differentially expression $(\mathrm{FC} \geq 2.0$ or $\leq 0.5, \mathrm{p} \leq 0.05)$."

These errors do not affect the conclusions of the Article.

(c) (i) Open Access This article is licensed under a Creative Commons Attribution 4.0 International License, which permits use, sharing, adaptation, distribution and reproduction in any medium or format, as long as you give appropriate credit to the original author(s) and the source, provide a link to the Creative Commons license, and indicate if changes were made. The images or other third party material in this article are included in the article's Creative Commons license, unless indicated otherwise in a credit line to the material. If material is not included in the article's Creative Commons license and your intended use is not permitted by statutory regulation or exceeds the permitted use, you will need to obtain permission directly from the copyright holder. To view a copy of this license, visit http://creativecommons.org/licenses/by/4.0/.

(C) The Author(s) 2020 